\title{
Milk yield, composition and cholesterol level in dairy cows fed rations supplemented with zinc and fatty acid calcium salts
}

\author{
F. Brzóska ${ }^{1}$ and J. Kowalczyk ${ }^{2}$ \\ 'Research Institute of Animal Production, Department of Feed Sciences \\ 32-083 Balice, Poland \\ ${ }^{2}$ The Kielanowski Institute of Animal Physiology and Nutrition, Polish Academy of Sciences \\ 05-110 Jablonna, Poland
}

(Received 31 January 2002; accepted 2 August 2002)

\begin{abstract}
In an experiment conducted on 16 Red-and-Whitc cows in a $2 \times 2$ Latin square design, the effect of two levels of zinc and calcium fatty acid salts on milk yield, composition and cholesterol level were studied. Cows were a fed diet consisting of maize and grass silage, ground barley, wheat bran and rapeseed meal with mineral mixtures, which in the control groups had a low level of $\mathrm{Zn}$ and fatty acid salts but in the experimental groups was supplemented with $6 \%$ (DM basis) calcium fatty acid salts and mineral mixture enriched with $6 \mathrm{~g} \mathrm{Zn} / \mathrm{kg}$ that corresponds to $480 \mathrm{mg} \mathrm{Zn/cow} /$ day. Intake of DM was $19.2 \pm 0.28 \mathrm{~kg} / \mathrm{d}$, in this $12.1 \pm 0.22 \mathrm{~kg}$ was from silages and $7.1 \pm 0.16$ from concentrate. Mean milk yield did not differ significantly between the treatments and was $26.2 \pm 0.68$ $\mathrm{kg} / \mathrm{day}$; cows on the diet with the higher level of $\mathrm{Zn}$ produced $0.9 \mathrm{~kg} /$ day less, those receiving fatty acid salts gave about $0.93 \mathrm{~kg} / \mathrm{d}$ more milk, but the differences did not reach statistical significance. Milk from cows fed the diet supplemented with $6 \%$ fatty acid salts contained less fat and protein $(P<0.05)$ but had a higher acidity $(P<0.01)$ and renneting time $(P<0.05)$. Enrichment of the diet with $\mathrm{Zn}$ did not significantly affect the content of the nitrogen fraction including casein. Addition of fatty acid salts to the dict resulted in a significant decrease of total- $N$, protein- $N$, casein- $N$ fractions $(P<0.01)$ and saturated fatty acids $(P<0.05)$ but increased the unsaturated fatty acid $(P<0.05)$ level in milk. The higher $\mathrm{Zn}$ level fed with the diet elevated its content in the blood $(P<0.01)$, whereas the level of other determined metabolites did not differ significantly between treatments. Feeding cows CaFA salts significantly elevated triglyceride, total cholesterol, $\operatorname{HDL}(\mathrm{P}<0.01)$, alkaline phosphatase and magnesium levels $(\mathrm{P}>0.05)$ in blood plasma. Feeding cows with diets supplemented with $\mathrm{Zn}$ or CaFA saits did not change milk total cholesterol levels, with the mean concentration in milk being $17.2 \pm 0.4 \mathrm{mg} / 100 \mathrm{ml}$.
\end{abstract}

KEY WORDS: dairy cow, feeding, zinc, calcium fatty acid salts, milk yicld, milk composition, cholesterol 


\section{INTRODUCTION}

Studies on laboratory animals suggest that lipid metabolism, including cholesterol, depends on the level of copper and zinc in the dict (Mazur et al., 1993; Rayssiguier et al., 1993). Studies aiming decreasing the cholesterol level in food of animal origin, mainly eggs and meat, have been undertaken by supplementing the diets for animals with various additives such as garlic, calcium salts of longchain unsaturated fatty acids, linseed or rape seed (Konjufca et al., 1997; Barowicz, 2000). Attempts to decrease the cholesterol level in cow's milk are not numerous and have not brought satisfactory results, e.g., lowering the $\mathrm{Cu}$ level in the diet for dairy cows failed to decrease the cholesterol level in milk (Brzóska and Sala, 2001). Other studies suggest that the $\mathrm{Zn}$ content in diets for dairy cows can modify the level of lipids in blood, as lower levels of $\mathrm{Zn}$ in the diet increase the lipid oxidation rate in the liver (Roussel et al., 1993). Kirchgessner et al. (1993) reported a lowered level of total and free cholesterol, triglycerides, phosphoglycerides and alkaline phosphatase activity in blood of rats fed a Zn-deficient diet; unfortunately the cholesterol content in milk of experimental animals was not determined.

The aim of the experiment was to test the hypothesis that a low content of $\mathrm{Zn}$ and addition of CaFA salts to the diet for dairy cows results in decreasing the cholesterol level in blood and milk, and to examine their effects on milk yield and composition.

\section{MATERIAL AND METHODS}

\section{Animals and diets}

The experiment was carried out on 16 Red-and-White dairy cows of $590 \pm 30$ $\mathrm{kg}$ body weight (BW), at 6-8 wecks after calving, in a two factorial $2 \times 2$ Latin square design to verify the effect of two levels of zinc or calcium fatty acid salts (CaFA salts) on milk yield, content of cholesterol and other components in milk. The experiment comprised 4 periods, each lasting 21 days, including 3 final days during which milk yield was measured and milk and blood from the jugular vein were sampled for analysis. All of the cows were fed grass and maize silages to appetite and offered concentrate in an amount of $0.28 \mathrm{~kg} / \mathrm{kg}$ milk. The rations were provided twice daily during milking at 7.00 and 16.00 . The concentrate was composed of ground barley, wheat bran and rapeseed oilmeal, dicalcium phosphate, limestone and common salt and contained $16 \%$ crude protein. A mineral mixture (BASF Kutno, Poland) with a low level of $\mathrm{Zn}$ and fatty acid salts were given to control groups; this diet was supplemented for experimental animals 
with $6 \%$ (DM basis) CaFA salts and enriched with $6 \mathrm{~g} \mathrm{Zn} / \mathrm{kg}$ which corresponded $480 \mathrm{mg} \mathrm{Zn/cow/day} \mathrm{(Table} \mathrm{1).} \mathrm{The} \mathrm{control} \mathrm{ration} \mathrm{was} \mathrm{deficient} \mathrm{in} \mathrm{Zn}$, whereas the experimental diet covered the requirement for this element; copper intake was maintained at a level of $230 \mathrm{mg} /$ day, which covered the requirements of cows for this element (MAFF, 1984; Rogers, 1996). CaFA salts in the form of the modified feed fat preparation Erafet was produced (Fosbac Co. Ltd., Wiag, Poland) from rape seed and fish oils $(0.8: 0.2)$ and given mixed with concentrate to experimental cows in the amount of $6 \%$ of diet DM, i.e. $900 \mathrm{~g}$ preparation per cow/day.

TABLE I

Ingredients of diets for dairy cows, $\% \mathrm{DM}$

\begin{tabular}{lcc}
\hline \multirow{2}{*}{ Itcm } & \multicolumn{2}{c}{ Diets } \\
\cline { 2 - 3 } & wthout CaFA & with CaFA \\
\hline Maize silage & 28.25 & 28.25 \\
Grass silage & 34.60 & 34.57 \\
Barley ground & 17.27 & 11.50 \\
Wheat bran & 10.40 & 8.40 \\
Rapeseed meal & 8.00 & 10.00 \\
CaFA salt (Erafet) & - & 6.00 \\
Limestone & 0.40 & 0.20 \\
Dicalcium phosphate & 0.60 & 0.60 \\
Magnesium oxide & 0.20 & 0.20 \\
Sodiun cliloride & 0.20 & 0.20 \\
Mineral premix & 0.08 & 0.08 \\
\hline
\end{tabular}

'content in g/ $\mathrm{kg}$ : Ca 100; P 100, Na 100. Mg 50, Zn 6, Mn 4, Cu 2.8 and I 0.1

\section{Chemical analyses}

The nutrient contents in feeds were determined by conventional methods (AOAC, 1990) and feed nutritive value was expressed according to the INRA-88 system and calculated using Winwar 1.3 software. Feed DM was determined at $105^{\circ} \mathrm{C}$ and its content in silages was adjusted for volatile substances (Dulphy and Demarquilly, 1981). Milk fat, protein, and lactose contents, renneting time, density and $\mathrm{pH}$ were determined according to Polish Standards (PN 68/A-86122; 1968). Total nitrogen and its fractions in milk were determined by the Kjeldahl procedure. Individual fatty acids in milk were assayed as methyl esters using a GLC Varian 3400 gas chromatograph with DB-FFAP column according to the method of Atwal et al. (1990). Five ml of milk were shaken with $35 \mathrm{ml}$ of chloroform-methanol mixture $(2: 1 \mathrm{v} / \mathrm{v})$ and centrifuged. Four $\mathrm{ml}$ of the bottom layer were evaporated in a nitrogen atmosphere and hydrolysed with $0.5 \mathrm{ml}$ for $20 \mathrm{~min}$ at $80^{\circ} \mathrm{C}$ and analy- 
sed. The glucose, urea, triglyceride, and cholesterol contents and selected enzyme activities in blood plasma were determined using enzyme-linked tests from Cormay Diagnostyka S.A. (Lublin, Poland). Minerals in feeds, milk and blood plasma were determined by atomic mass spectroscopy using Philips PU 9000 equipment.

\section{Statistical analysis}

The results were subjected to statistical analysis of variance using the Statgraphic 6.0 software package to determine the influence of zinc, fat and their interactions on the analysed parameters.

\section{RESULTS}

The composition of the rations, nutrient contents, and nutritive value are given in Tables 1 and 2. Intake of dietary DM was $19.2 \pm 0.28 \mathrm{~kg} / \mathrm{d}$, including $12.1 \pm 0.22 \mathrm{~kg}$

TABLE 2

Chemical composition and mutritive value of feeds

\begin{tabular}{|c|c|c|c|c|}
\hline \multirow[b]{2}{*}{ Item } & \multirow{2}{*}{$\begin{array}{l}\text { Maize } \\
\text { silage }\end{array}$} & \multirow{2}{*}{$\begin{array}{l}\text { Grass } \\
\text { silage }\end{array}$} & \multicolumn{2}{|c|}{ Concentrate } \\
\hline & & & without $\mathrm{CaFA}$ & $\begin{array}{l}\text { with } \\
\text { CaFA }\end{array}$ \\
\hline Dry matter, $\%$ & 23.96 & 37.47 & 85.66 & 867.7 \\
\hline Nutrients, g. $\mathrm{kg}^{-1} \mathrm{DM}$ & & & & \\
\hline organic matter & 962.3 & 919.1 & 961.3 & 944.6 \\
\hline crude protein & 68.8 & 164.6 & 163.0 & 156.5 \\
\hline ether extract & 31.8 & 42.4 & 34.7 & 56.2 \\
\hline crude fibre & 283.1 & 277.4 & 72.2 & 70.9 \\
\hline $\mathrm{N}$-free extractives & 578.6 & 434.7 & 691.4 & 661.0 \\
\hline ash & 37.7 & 80.9 & 38.7 & 55.4 \\
\hline NDF & 452.0 & 431.1 & - & - \\
\hline $\mathrm{ADF}$ & 303.1 & 294.4 & - & - \\
\hline $\mathrm{ADL}$ & 40.9 & 43.2 & - & - \\
\hline $\mathrm{Ca}$ & 3.38 & 7.48 & 7.15 & 8.50 \\
\hline $\mathrm{P}$ & 1.87 & 3.82 & 6.95 & 5.75 \\
\hline $\mathrm{Mg}$ & 1.01 & 2.46 & 3.01 & 2.65 \\
\hline $\mathrm{Zn}, \mathrm{mg} \cdot \mathrm{kg}^{-1}$ & 36.15 & 34.78 & 33.73 & 31.98 \\
\hline $\mathrm{ME}, \mathrm{MJ}$ & 10.48 & 9.68 & 12.18 & 13.40 \\
\hline $\mathrm{NEL}, \mathrm{MJ}$ & 6.34 & 5.69 & 6.88 & 7.51 \\
\hline UFL & 0.91 & 0.88 & 1.01 & 1.20 \\
\hline PDIN & 42.3 & 95.9 & 109.5 & 108.7 \\
\hline PDIE & 73.8 & 80.3 & 99.7 & 99.2 \\
\hline
\end{tabular}


from silages and $7.1 \pm 0.16$ from concentrate. Daily zinc intake in the control group was $631 \mathrm{mg} \mathrm{Zn} /$ day and in the experimental group, $1142 \mathrm{mg} \mathrm{Zn/day} \mathrm{which}$ equals a $\mathrm{Zn}$ concentration of 32.8 or $59.4 \mathrm{mg} / \mathrm{kg} \mathrm{DM}$ of ration. The average milk yield was similar in all groups of animals, amounting to $26.2 \pm 0.68 \mathrm{~kg} / \mathrm{day}$ with a slight, but not significant, tendency to be lower $(0.9 \mathrm{~kg} /$ day $)$ in the animals receiving the diet with the higher level of $\mathrm{Zn}$. Milk yield was significantly higher in the animals kept on the diet supplemented with CaFA salts $(\mathrm{P}<0.05)$. Daily production of fat, protein and lactose $(\mathrm{kg} / \mathrm{day})$ in milk was not affected $(\mathrm{P}>0.05)$ by the $\mathrm{Zn}$ or CaFA salt levels in the diets, but the concentration of fat and protein in milk of cows kept on diets supplemented with $6 \% \mathrm{CaFA}$ salts was lower $(\mathrm{P}<0.05)$ than in milk of the control group. Acidity and renetting time of milk from cows fed the CaFA salts diet were significantly higher $(\mathrm{P}<0.01)$ but did not influence milk density. The differentiated level of $\mathrm{Zn}$ in diets did not significantly influence the value of these parameters (Table 3).

TABLE 3

Feed intake, milk yield and composition

\begin{tabular}{|c|c|c|c|c|c|c|c|c|}
\hline \multirow[b]{2}{*}{ liem } & \multicolumn{2}{|c|}{ Level of $Z n$} & \multicolumn{2}{|c|}{ CaFA salt } & \multirow[t]{2}{*}{$\mathrm{SE}$} & \multicolumn{3}{|c|}{ Pvalue } \\
\hline & low & high & $\begin{array}{l}\text { with- } \\
\text { out }\end{array}$ & with & & $\begin{array}{l}\text { zince } \\
\text { (z) }\end{array}$ & $\begin{array}{l}\text { fat } \\
\text { (f) }\end{array}$ & $z \times f$ \\
\hline Feed intake, $\mathrm{kgDM} / \mathrm{d}$ & 19.35 & 19.09 & 19.00 & 19.44 & 0.28 & 0.643 & 0.436 & 0.747 \\
\hline silage & 12.05 & 12.11 & 12.00 & 12.17 & 0.22 & 0.894 & 0.696 & 0.697 \\
\hline maize & 5.41 & 5.44 & 5.37 & 5.49 & 0.11 & 0.870 & 0.596 & 0.792 \\
\hline grass & 6.63 & 6.67 & 6.62 & 6.68 & 0.21 & 0.943 & 0.889 & 0.788 \\
\hline concentrate & 7.30 & 6.98 & 7.01 & 7.27 & 0.16 & 0.320 & 0.417 & 0.989 \\
\hline $\min$ & 0.08 & 0.08 & 0.08 & 8 & 0.00 & 0.380 & 0.502 & 0.897 \\
\hline Milk yio & 26.83 & 25.62 & 25.76 & 26.76 & 0.68 & 0.380 & 0.502 & 0.897 \\
\hline $\mathrm{FCM}, \mathrm{kg} / \mathrm{d}^{\prime}$ & 27.47 & 25.77 & 26.84 & 26.44 & 0.72 & 0.168 & 0.274 & 0.658 \\
\hline fat, $\%$ & 4.16 & 4.04 & 4.28 & 3.92 & 0.05 & 0.242 & 0.001 & 0.288 \\
\hline protein, $\%$ & 2.99 & 2.99 & 3.08 & 2.89 & 0.03 & 0.974 & 0.001 & 0.983 \\
\hline lactose, $\%$ & 5.09 & 5.01 & 5.01 & 5.08 & 0.03 & 0.227 & 0.247 & 0.703 \\
\hline fatt, $\mathrm{gd}^{-1}$ & 1103 & 1030 & 1095 & 1038 & 27 & 0.188 & 0.302 & 0.713 \\
\hline protein, $\mathrm{gd}^{-1}$ & 795 & 760 & 782 & 773 & 18 & 0.349 & 0.795 & 0.777 \\
\hline lactose, $g d^{\prime}$ & 1367 & 1286 & 1295 & 1359 & 37 & 0.286 & 0.398 & 0.940 \\
\hline Acidity, ${ }^{\circ} \mathrm{SH}$ & 6.33 & 6.38 & 6.81 & 5.90 & 0.09 & 0.732 & 0.000 & 0.846 \\
\hline Remneting time, $\mathrm{s}$ & 119 & 112 & 99 & 132 & 8 & 0.632 & 0.039 & 0.433 \\
\hline Density, $\mathrm{g} / \mathrm{cm}^{3}$ & 1.0291 & 1.0297 & 1.0297 & 1.0291 & 0.0001 & 0.113 & 0.138 & 0.113 \\
\hline
\end{tabular}

FCM-milk corrected for $4 \%$ of fat 
Cholesterol, $\mathrm{Ca}, \mathrm{P}, \mathrm{Mg}$ and $\mathrm{Zn}$ levels in milk were not affected by the $\mathrm{Zn}$ level in diets $(\mathrm{P}>0.05)$ but feeding the diet supplemented with CaFA salts significantly $(\mathrm{P}<0.05)$ increased the $\mathrm{Ca}, \mathrm{P}$ and $\mathrm{Mg}$ concentrations in milk (Table 4).

TABLE 4

Total cholesterol and minerals content in milk

\begin{tabular}{|c|c|c|c|c|c|c|c|c|}
\hline \multirow[b]{2}{*}{ Item } & \multicolumn{2}{|c|}{ Level of $\mathrm{Zn}$} & \multicolumn{2}{|c|}{ CaFA salt } & \multirow[b]{2}{*}{ SE } & \multicolumn{3}{|c|}{ Pvalue } \\
\hline & low & high & $\begin{array}{c}\text { with- } \\
\text { out }\end{array}$ & with & & $\begin{array}{c}\text { zinc } \\
(\mathrm{z})\end{array}$ & $\begin{array}{l}\text { fat } \\
\text { (f) }\end{array}$ & $7 \times 1$ \\
\hline Total cholestcrol, $\mathrm{mg} / 100 \mathrm{ml}$ & 17.26 & 17.09 & 17.43 & 16.91 & 0.40 & 0.832 & 0.523 & 0.832 \\
\hline $\mathrm{Ca}, \mathrm{mg} / 100 \mathrm{~g}$ & 121.4 & 122.3 & 117.8 & 126.0 & 1.3 & 0.710 & 0.001 & 0.283 \\
\hline $\mathrm{P}, \mathrm{mg} / 100 \mathrm{~g}$ & 101.2 & 102.4 & 96.5 & 107.2 & 1.3 & 0.591 & 0.000 & 0.931 \\
\hline $\mathrm{Mg}, \mathrm{mg} / 100 \mathrm{~g}$ & 9.8 & 9.9 & 9.6 & 10.1 & 0.1 & 0.576 & 0.044 & 0.813 \\
\hline $\mathrm{Zn}, \mathrm{mg} / 100 \mathrm{~g}$ & 0.53 & 0.53 & 0.52 & 0.54 & 0.02 & 0.873 & 0.164 & 0.838 \\
\hline
\end{tabular}

The concentration of nitrogen fractions, including casein-N, as well as the fatty acid composition of milk were not affected by the level of $\mathrm{Zn}$ in the rations. Rations supplemented with CaFA salts decreased $(\mathrm{P}<0.01)$ the concentration of total- $\mathrm{N}$, protein- $\mathrm{N}$, casein- $\mathrm{N}$ and the ratio of cascin- $\mathrm{N}$ to total- $\mathrm{N}$ (Table 5) and content of saturated (lauric, palmitic) fatty acids in milk ( $\mathrm{P}<0.05)$, but the content of mono- and polyunsaturated fatty acids: oleic, linolenic, conjugated linoleic $(\mathrm{P}<0.01)$ and eicosopentaenoic $(\mathrm{P}<0.05)$, increased. Hypocholesterolemic (DFA) acid levels were higher, while hypercholesterolemic acids (OFA) were lower in the milk of cows fed CaFA salts $(\mathrm{P}<0.01)$ (Table 6).

TABLE 5

Nitrogen fraction in the milk, \%

\begin{tabular}{|c|c|c|c|c|c|c|c|c|}
\hline \multirow[b]{2}{*}{ Item } & \multicolumn{2}{|c|}{ Level of $\mathrm{Zn}$} & \multicolumn{2}{|c|}{ CaFA salt } & \multirow[b]{2}{*}{ SE } & \multicolumn{3}{|c|}{ Pvalue } \\
\hline & low & high & without & with & & $\begin{array}{c}\text { zinc } \\
(\mathrm{z})\end{array}$ & $\begin{array}{l}\text { fat } \\
(f)\end{array}$ & $\mathrm{zxf}$ \\
\hline Total N & 0.472 & 0.475 & 0.493 & 0.454 & 0.005 & 0.724 & 0.000 & 0.646 \\
\hline True protein $\mathrm{N}$ & 0.446 & 0.444 & 0.461 & 0.429 & 0.005 & 0.832 & 0.003 & 0.799 \\
\hline Cascin N & 0.477 & 0.381 & 0.398 & 0.360 & 0.005 & 0.667 & 0.000 & 0.728 \\
\hline Whey N & 0.095 & 0.095 & 0.095 & 0.095 & 0.001 & 0.531 & 0.561 & 0.871 \\
\hline NPN & 0.028 & 0.028 & 0.028 & 0.028 & 0.006 & 0.889 & 0.692 & 0.625 \\
\hline $\begin{array}{l}\text { True protein N, \% } \\
\text { of total } \mathrm{N}\end{array}$ & 93.92 & 94.13 & 93.89 & 94.17 & 0.15 & 0.498 & 0.357 & 0.908 \\
\hline $\begin{array}{c}\text { Casein } \mathrm{N}, \% \\
\text { of total } \mathrm{N}\end{array}$ & 79.85 & 80.00 & 79.22 & 80.63 & 0.26 & 0.763 & 0.007 & 0.863 \\
\hline
\end{tabular}


TABLE 6

Fatty acid composition of the milk fat, $\mathrm{g} / 100 \mathrm{~g}$ of total fatty acids

\begin{tabular}{|c|c|c|c|c|c|c|c|c|}
\hline \multirow[b]{2}{*}{ Item } & \multicolumn{2}{|c|}{ Level of $\mathrm{Zn}$} & \multicolumn{2}{|c|}{ CaFA salt } & \multirow[b]{2}{*}{$\mathrm{SE}$} & \multirow{2}{*}{\multicolumn{2}{|c|}{$\begin{array}{c}\text { P value } \\
\text { fat } \\
\text { (f) }\end{array}$}} & \multirow[b]{2}{*}{$2 \times f$} \\
\hline & low & high & without & with & & & & \\
\hline $\mathrm{C}_{8}$ & 2.01 & 1.98 & 2.04 & 1.95 & 0.05 & 0.829 & 0.089 & 0.301 \\
\hline $\mathrm{C}_{10}$ & 3.87 & 3.82 & 4.03 & 3.65 & 0.11 & 0.789 & 0.439 & 0.465 \\
\hline $\mathrm{C}_{12}$ & 4.16 & 4.10 & 4.38 & 3.88 & 0.13 & 0.803 & 0.045 & 0.451 \\
\hline $\mathrm{C}_{14}$ & 12.76 & 12.39 & 12.99 & 12.16 & 0.28 & 0.506 & 0.138 & 0.333 \\
\hline $\mathrm{C}_{16}$ & 36.44 & 35.93 & 38.36 & 34.01 & 0.59 & 0.640 & 0.000 & 0.897 \\
\hline$C_{16: 1}$ & 1.40 & 1.44 & 1.46 & 1.38 & 0.03 & 0.449 & 0.253 & 0.255 \\
\hline $\mathrm{C}_{18}$ & 11.38 & 10.89 & 10.81 & 11.46 & 0.25 & 0.328 & 0.188 & 0.064 \\
\hline$C_{18: 1}$ & 23.62 & 24.58 & 21.93 & 26.27 & 0.71 & 0.471 & 0.002 & 0.995 \\
\hline$C_{18: 2}$ & 2.37 & 2.58 & 2.23 & 2.72 & 0.10 & 0.291 & 0.017 & 0.707 \\
\hline$C_{6 \times: 3 n-6}$ & 0.34 & 0.36 & 0.27 & 0.42 & 0.03 & 0.675 & 0.008 & 0.902 \\
\hline$C_{t x: 3 n-3}$ & 0.86 & 1.02 & 0.75 & 1.13 & 0.08 & 0.298 & 0.014 & 0.677 \\
\hline CLA & 0.56 & 0.57 & 0.48 & 0.65 & 0.03 & 0.828 & 0.002 & 0.488 \\
\hline$C_{20: 0}$ & 0.14 & 0.13 & 0.13 & 0.13 & 0.005 & 0.391 & 0.705 & 0.142 \\
\hline$C_{20: 4}$ & 0.12 & 0.11 & 0.12 & 0.11 & 0.005 & 0.292 & 0.207 & 0.914 \\
\hline $\mathrm{C}_{22: 5}$ & 0.06 & 0.05 & 0.05 & 0.06 & 0.003 & 0.143 & 0.019 & 0.426 \\
\hline $\mathrm{C}_{22: 0}$ & 0.06 & 0.06 & 0.07 & 0.06 & 0.004 & 0.744 & 0.092 & 0.157 \\
\hline$C_{22: 1}$ & 0.01 & 0.01 & 0.01 & 0.01 & 0.003 & 0.181 & 0.359 & 0.656 \\
\hline SFA & 70.81 & $69.3 !$ & 72.81 & 67.31 & 0.90 & 0.378 & 0.002 & 0.945 \\
\hline UFA & 29.19 & 30.69 & 27.19 & 32.69 & 0.90 & 0.378 & 0.002 & 0.945 \\
\hline MUFA & 24.94 & 26.02 & 23.32 & 27.63 & 0.73 & 0.434 & 0.003 & 0.956 \\
\hline PUFA & 4.25 & 4.67 & 3.86 & 5.06 & 0.22 & 0.314 & 0.005 & 0.920 \\
\hline PUFA-6 & 2.81 & 3.05 & 2.61 & 3.24 & 0.12 & 0.313 & 0.012 & 0.664 \\
\hline PUFA-3 & 0.91 & 1.06 & 0.79 & 1.18 & 0.08 & 0.930 & 0.007 & 0.770 \\
\hline DFA & .41 .11 & 41.26 & 38.54 & 43.86 & 0.99 & 0.594 & 0.002 & 0.671 \\
\hline OFA & 59.43 & 58.42 & 62.01 & 55.84 & 1.01 & 0.280 & 0.004 & 0.581 \\
\hline PUFA-6/PUFA-3 & 0.42 & 0.47 & 0.38 & 0.51 & 0.02 & 0.501 & 0.003 & 0.859 \\
\hline UFA/SFA & 0.71 & 0.76 & 0.63 & 0.83 & 0.03 & 0.827 & 0.006 & 0.762 \\
\hline DFA/OFA & 0.37 & 0.40 & 0.33 & 0.44 & 0.02 & 0.501 & 0.003 & 0.859 \\
\hline MUFA/SFA & 0.06 & 0.07 & 0.05 & 0.08 & 0.005 & 0.393 & 0.001 & 0.748 \\
\hline PUFA/SFA & 3.35 & 3.31 & 3.57 & 3.09 & 0.09 & 0.231 & 0.005 & 0.610 \\
\hline
\end{tabular}

Metabolite levels determined in blood plasma were not altered by the level of $\mathrm{Zn}$ in the diet, but cows fed rations with CaFA salts had increased concentrations of triglycerides, total cholesterol, high density lipoprotein (HDL), alkaline phosphatase (ALP), and magnesium, whereas the remaining metabolite levels were similar as in the plasma of control animals (Table 7). 
TABLE 7

Metabolite and minerals content in blood plasma

\begin{tabular}{|c|c|c|c|c|c|c|c|c|}
\hline \multirow[b]{2}{*}{ Item } & \multicolumn{2}{|c|}{ Level of $\mathrm{Zn}$} & \multicolumn{2}{|c|}{ CaFA salt } & \multirow[b]{2}{*}{ SE } & \multicolumn{3}{|c|}{ Pvalue } \\
\hline & low & high & $\begin{array}{l}\text { wit- } \\
\text { hout }\end{array}$ & with & & $\begin{array}{c}\text { zinc } \\
(z)\end{array}$ & $\begin{array}{l}\text { fat } \\
\text { (f) }\end{array}$ & $\mathrm{z} \times \mathrm{f}$ \\
\hline Glucose, $\mathrm{mg} / 100 \mathrm{~g}$ & 57.10 & 57.14 & 58.87 & 56.95 & 1.85 & 0.942 & 0.202 & 0.942 \\
\hline Urea, $\mathrm{mg} / 100 \mathrm{~g}$ & 12.47 & 11.04 & 12.99 & 10.51 & 0.71 & 0.315 & 0.083 & 0.367 \\
\hline Triglycerols. $\mathrm{mg} / 100 \mathrm{~g}$ & 6.22 & 6.25 & 5.52 & 6.96 & 0.31 & 0.967 & 0.019 & 0.892 \\
\hline Total cholesterol, mg/100 g & 233.90 & 226.43 & 203.98 & 256.34 & 8.32 & 0.633 & 0.001 & 0.565 \\
\hline HDL, $m g / 100 \mathrm{~g}$ & 190.33 & 188.69 & 170.51 & 208.51 & 5.70 & 0.877 & 0.001 & 0.585 \\
\hline LDL, $m g / 100 \mathrm{~g}$ & 28.67 & 31.78 & 33.48 & 26.97 & 2.02 & 0.441 & 0.110 & 0.545 \\
\hline AST, U/L & 54.15 & 52.23 & 52.03 & 53.55 & 1.22 & 0.442 & 0.770 & 0.8 .34 \\
\hline ALT, U/L & 27.99 & 26.66 & 28.49 & 26.16 & 0.92 & 0.473 & 0.213 & 0.567 \\
\hline ALP, U/L & 14.39 & 15.31 & 15.73 & 14.97 & 2.04 & 0.816 & 0.062 & 0.769 \\
\hline $\mathrm{LDH}, \mathrm{U} / \mathrm{L}$ & 889.9 & 893.61 & 886.30 & 888.29 & 18.47 & 0.740 & 0.958 & 0.827 \\
\hline $\mathrm{Ca}, \mathrm{mg} / 100 \mathrm{~g}$ & 14.02 & 15.00 & 14.15 & 14.86 & 0.37 & 0.335 & 0.188 & 0.828 \\
\hline $\mathrm{P}, \mathrm{mg} / 100 \mathrm{~g}$ & 9.40 & 9.81 & 9.54 & 9.67 & 0.30 & 0.494 & 0.832 & 0.365 \\
\hline $\mathrm{Mg}, \mathrm{mg} / 100 \mathrm{~g}$ & 2.35 & 2.39 & 2.32 & 2.42 & 0.02 & 0.353 & 0.048 & 0.634 \\
\hline $\mathrm{Zn}, \mathrm{mg} / 100 \mathrm{~g}$ & 0.40 & 0.44 & 0.40 & 0.41 & 0.01 & 0.011 & 0.661 & 0.763 \\
\hline
\end{tabular}

AST - aspartate aminotransferase

ALT - alanine aminotransferase

ALP - alkaline phosphatase

LDH - lactate dehydrogenase

\section{DISCUSSION}

The requirements of milking cows for $\mathrm{Zn}$ depends on their milk yield, and a value 600-800 $\mathrm{mg} \mathrm{Zn} /$ day is accepted (MAFF, 1984; Rogers, 1996). This means that at an intake of $20 \mathrm{~kg}$ of $\mathrm{DM} / \mathrm{d}$, the concentration of $\mathrm{Zn}$ in the diet should be $30-40 \mathrm{mg} / \mathrm{kg}$ DM. The Zn contents of roughage depend on the $\mathrm{Zn}$ level in the soil. Analysis of the $\mathrm{Zn}$ content in fodder plants gave values of 24.5 in meadow fescue, 38.0 in cocksfoot, and about $30 \mathrm{mg} / \mathrm{kg}$ DM in cereals. The variability of $\mathrm{Zn}$ content in fodder plants was $\pm 40 \%$ depending on the site, soil parameters and rainfall intensity. Assimilation of $\mathrm{Zn}$ from roughage, according to Rogers (1996), is low and does not exceed $30 \%$ since in the digesta, phytic acid of plant origin creates insoluble compounds with $\mathrm{Zn}, \mathrm{Ca}$ and $\mathrm{Cu}$ (Ashes and Jeppsen, 1993). Therefore, the main source of microelements for dairy cows are premixes, mineral mixtures or metal-organic chelate compounds.

The results of the present experiment demonstrated that decreasing the $\mathrm{Zn}$ content in diets for milking cows to the level of its content in natural roughage and concentrate without including $\mathrm{Zn}$ in the mineral mixture did not significantly lower milk yield or its components such as fat, protein, and lactose; milk acidi- 
ty, renneting time and density did not differ significantly between the respective groups of cows.

Daily milk yield was $0.93 \mathrm{~kg}$ higher in cows fed the diet with CaFA salts than in control animals, however this difference was not statistically significant. In an earlier similar experiment by Bielak et al. (1994), cows fed diets supplemented with CaFA salts produced $1.73 \mathrm{~kg}$ milk more than without this supplement. Kim et al. (1991), Schauff et al. (1992), Bielak et al. (1994) or Potkański et al. (1997) reported that supplementing diets with CaFA salts for milking cows resulted in decreased fat and even protein content in produced milk. The Erafet preparation is produced from a mixture of rape seed and fish oils and represents a mixture of fatty acids calcium salts and glycerol obtained through alkaline hydrolysis of fats. The decrease in the fat content in the milk of cows fed the CaFA salts diet might be induced by glycerol, which is a source of more easily available energy for bacteria in the rumen than energy from dietary fibre. Decreased fibre digestion could explain the lower content of fat in the milk.

Lower protein content in milk from cows fed diets with the addition of $\mathrm{CaFA}$ salts are documented in numerous experiments (e.g., Andrew et al., 1991; Schauff and Clark, 1992; Brzóska et al., 1999a,b) but the reason is still not understood. There are some suggestions that feeding cows diets with CaFA salts may decrease the blood level of somatotropin secreted by the pituitary gland. Casper and Schingoethe (1989) suggested that absorption of amino acids from the blood into the mammary gland is controlled by somatotropin and insulin, therefore consequently affects milk protein synthesis.

Acidity and renneting time of milk from cows fed the diet supplemented with CaFA salts were significantly higher than in milk from control cows, but the density of milk from cows of both groups was similar. It may be suggested that feeding the diet with CaFA salts resulted in increased fatty acid levels in the blood of cows, leading to increased oxidation in the animals' bodies, which in turn might raise the milk bicarbonate level and acidity. This fact, hitherto not confirmed by other investigations, may influence the suitability of milk for production of dairy products.

Differentiated levels of $\mathrm{Zn}$ in the diets did not affect the total cholesterol concentration in milk, which suggests that there is no dependence between the level of $\mathrm{Zn}$ in the diet and cholesterol concentration in blood and milk of cows. This finding does not support the data obtained by Kirchgessner et al. (1993) in experiments on laboratory animals, since in the plasma of $\mathrm{Zn}$-deficient rats, the total cholesterol $(-31 \%)$, free cholesterol $(-49 \%)$, triglyceride $(-46 \%)$, phospholipid $(-22 \%)$ concentrations and alkaline phosphatase activity $(-45 \%)$ were lower compared with rats fed diets with higher $\mathrm{Zn}$ levels. The results obtained in the present experiments with cows did not demonstrate a similar tendency as in rats. However, the contrast in the levels in $\mathrm{Zn}$ content in the diets for rats was more pronounced than in diets for cows, as in the control diets for cows, silage and concentrate contained slight 
amounts of $\mathrm{Zn}$. This suggests that a lowered $\mathrm{Zn}$ level in the diet for cows did not affect 3-hydroxy-3-metylglutaryl-CoA which is responsible for low density lipoprotein (LDL) synthesis in the liver of mammals. Our data indicates that $\mathrm{Zn}$ is not a factor influencing the activity of this enzyme.

The triglyceride and total cholesterol concentrations in the blood of cows fed the diet with CaFA salts were significantly higher than in the control group, confirming the results of other experiments (West and Hill, 1990; Christensen et al., 1994; Brzóska et al., 1999a,b). The higher level of total cholesterol in the blood of animals fed CaFA did not result in elevating its concentration in milk. The cholesterol concentration in milk was rather stable and changed only in a small range between the groups of cows, but its mean value was slightly higher than reported in other studies (Pabst and Walte, 1991; Brzóska and Sala, 2001). This suggests that the milk cholesterol level does not depend on its content in blood plasma and is modulated in the process of milk component synthesis. It can not be excluded that the epithelium of the mammary gland contains milk cholesterol receptors that catch the excess cholesterol from plasma. Our results suggest that the level of $\mathrm{Zn}$ and CaFA salts in the diet does not affect the cholesterol level in milk. A similar situation was found in the case of $\mathrm{Zn}$ transport from plasma, as its level in milk did not depend on the $\mathrm{Zn} \mathrm{level} \mathrm{in} \mathrm{the} \mathrm{diet} \mathrm{or} \mathrm{blood.} \mathrm{However,} \mathrm{transport} \mathrm{of} \mathrm{Ca}, \mathrm{P}$ and $\mathrm{Mg}$ from plasma into milk is controlled by different mechanisms, since the higher level of $\mathrm{Ca}$ in the diet and blood plasma resulted in a significant increase of these elements in milk.

The content of protein- $\mathrm{N}$ and casein- $\mathrm{N}$ in milk was not affected by the $\mathrm{Zn}$ level in rations but the contents of total- $\mathrm{N}$, protein- $\mathrm{N}$ and casein- $\mathrm{N}$ in milk from cows fed diets containing CaFA were significantly lower than in the milk of the cows kept on the diet without CaFA salts.

The level of $\mathrm{Zn}$ in the diet did not change the profile of fatty acids in milk as their concentration in milk was similar in both groups of cows. Feeding cows diets containing CaFA produced from vegetable and fish oils changed the profile of fatty acids in milk. The milk of this group of cows contained less saturated fatty acids but more unsaturated acids such as oleic, linolcic from the n-3 and n-6 families, conjugated linoleic and eicosopentacnoic acids as compared with the fatty acid composition of control milk. As a result of these changes in the fatty acid profile of milk, the proportion of acids in total fatty acids was $43 \%$ whereas in milk of the control group it was significantly lower, $38 \%$. The $\mathrm{Zn}$ level in the diet did not change the fatty acid profile and the proportion of hypocholesterolemic acids was $41 \%$ in the milk of both groups of cows. These results are in accordance with changes in fatty acid profiles described in experiments carried out with cows fed diets supplemented with different types of fat as canola seeds, rape seeds 00, tallow or CaFA salts (Mansbridge and Blake, 1997; Brzóska et al., 1999a,b). 
Feeding cows with diets differing in their $\mathrm{Zn}$ level did not result in changes in the levels of glucose, urea, triglycerides, total cholesterol and its fractions, enzymes or macroelements, but the $\mathrm{Zn}$ level was significantly higher in the blood plasma of cows fed supplemented diets. This suggests that the concentration of $\mathrm{Zn}$ in dicts for dairy cows does not affect the indices of energy, protein and fat metabolism in cows. Kirchgessner et al. (1993) reported that the activity of alkaline phosphatase in blood is correlated with the dietary $\mathrm{Zn}$ level, but such a dependence was not found in our experiment.

Feeding cows dicts containing CaFA salts significantly increased the concentration of triglycerides, total cholesterol, high density lipoproteins (HDL), and magnesium similarly as reported by other authors (Drackley et al., 1994; LaCount et al., 1994; Brzóska et al., 1999a). Increased triglyceride concentrations in blood plasma at their higher dietary intake is evident as they are highly digested in the digestive tract of cows. The increased concentration of HDL in blood plasma might be caused by increased delivery of long-chain fatty acids protected from biohydrogenation in the rumen, enhancing their concentration in blood plasma. The higher level of HDL in blood may stimulate the mammary gland to increase the content of unsaturated fatty acids in milk fat. On the other hand, long-chain fatty acids are known as a factor decreasing the LDL content in the liver, which at their declining tendency in blood plasma, could influence the increased HDL content. The significant effect of dietary CaFA salts on alkaline phosphatase activity and magnesium content in blood plasma obtained in our study was not found in earlier studies and is rather difficult to explain.

The level of cholesterol in milk changes to some degree depending on its level in blood plasma, suggesting the existence of regulatory mechanisms governing its level in milk, probably in the epithelial cells of the mammary gland adapted to synthesis of milk. This mechanism is independent of $\mathrm{Zn}$ levels ranging from 39 to $59 \mathrm{mg} \mathrm{Zn} / \mathrm{kg}$ of ration dry matter and CaFA salts in the range from 0 to $6 \%$ in dry matter of diets for cows.

\section{CONCLUSIONS}

Feeding dairy cows a diet with the addition of calcium fatty acid salts, produced from a mixture of rape seed and fish oils, does not increase milk yield or cholesterol level, but significantly elevates the level of unsaturated fatty acids, acidity and renneting time. It also slightly decreases the milk protein and fat contents.

Zine at levels ranging from 39 to $59 \mathrm{mg} / \mathrm{kg}$ of the diet for dairy cows does not affect milk yield, cholesterol or other metabolite levels in blood plasma or milk. Cows fed diets with higher levels of zinc efficiently absorb this element, increasing its concentration in blood plasma but not in milk, suggesting the existence of a mechanism blocking its transport into the milk. 


\section{ACKNOWLEDGENS}

The staff of Central Laboratory of the Research Institute of Animal Production is gratefully acknowledged for chemical and statistical analysis, and BASF in Kutno (Poland) for producing the mineral premix.

\section{REFERENCES}

Andrew S.M., Tyrrel H.F., Reynolds C.K., Erdman R.A., 1991. Net energy for lactation of calcium salts of long-chain fatty acids for cows fed silage-based diets. J. Dairy Sci. 74, 2588-2600

A.O.A.C., 1990. Official Methods of Analysis, Association of Analytical Chemists. $15^{\text {th }}$ Edition. Arlington, VA

Atwal A.S., Hidiroglou M., Kramer J.K.G., Binns M.R., 1990. Manipulation of the fatty acids composition of milk by fecding protected canola seeds. J. Dairy Sci. 75, 1090-1096

Ashes H,D., Jeppsen R.B., 1993. Mineral amino acids chelates in nutrition. In: M. Anke, D. Meisner, C.F. Mills (Editors). Trace Elements in Men and Animals. Jena (Germany)

Barowicz T., 2000. The effect of Ca-fatty acid salts of linsecd oil on cholesterol content in longissimus dorsi mussele of finishing pigs. In: Quality of Meat and Fat as Affected by Genetics and Nutrition. Wageningen Pers, Wageningen, pp. 225-228

Bielak F. Wawrzyńczak S., Kraszewki J., Strzadała B., 1994. Efficiency of supplemented fodder fat in feed rations of Red-and-White cows (in Polish). Rocz. Nauk Zool. 21 (1-2), 145-155

Brzóska F., Gạsior R., Sala K., Zyzak W., 1999a. Effect of calcium salts of fatty acids on cow performance and milk composition (in Polish). Roc7. Nauk Zoot. 26 (3), 143-157

Brzóska F., Gąsior R., Sala K., Zyzałk W., 1999b. Effect of linseed oil fatty acid calcium salts on vitamin and vitamin $\mathrm{E}$ on milk yicld and composition. J. Anim. Feed Sci. 8, 367-378

Brzóska F., Sala K., 2001. The effect caleium salt of fatty acids and copper in daily ration on milk yield and composition, and cholesterol level in cow's milk. J. Anim. Feed Sci. 10, Suppl. 2. 71 -76

Casper D.P., Schingoethe D.J., 1989. Model to describe and alleviate milk protein depression in early lactation cows fed a high fat diet. J. Dairy Sci. 72, 3327.3335

Christensen R.A., Drackley J.K., LaCount D.W., Clark J.H., 1994. Infusion of four long-chain fatty acids mixtures into the abomasum of lactating dairy cows. J. Dairy Sci. 77, 1052-1069

Dracley J.K., Grum D.E., McCoy D.C., Klusmayer T.H., 1994. Comparison of three methods for incorporation of Hiquid fat into dicts for lactating dairy cows. J. Dairy Sci. 77, 1386-1399

Dulpy J.I', Demarquilly C., 1981. Problens particuliers aux ensilages prevision de la valuer nutritive des aliments des ruminants. INRA Publ., pp. 81-104

Kim Y.K., Shingoethe D.J., Caspar D.P., Ludens F.C., 1991. Lactational response of dairy cows to increased crude dietary fiber and added fat. J. Dairy Sci. 74, 3871-3899

Kirchgessner M., Shülein A., Roth H.P., Schliack M., 1993. Inffuence of dietary zinc depletion on the concentration of cholesterol, phospholipids and triglicerides in serum and lipoprotein fractions of force-fed rats. In: A. Anke, D. Meissner, C.F. Mills (Editors). Proceedings of the $8^{\text {th }}$ International Symposium on Trace Elements in Man and Animals - THEMA 8. Verlag Media Turistik, pp. 78

Konjufca V.H., Pesti G.M., Bakalli R.l.. 1997. Modulation of cholesterol levels in broiler meat by dietary garlic and copper. Poultry Sci. 76, 1264-1271

LaCount D.W., Dracley J.K., Laesh S.O., Clark J.H., 1994. Sccretion of olcic acid in milk lat in response to abomasal infusion of canola or high oicic sunflower fatty acids. 3. Dairy Sci. 77, 1372-1385 
MAFF, DAFS, DANI, UKASTA, BVA Working Party Report, 1984. Mineral, trace element and vitamin allowances for ruminant livestock. In: W. Haresign, J.A. Cole (Editors). Recent Advances in Animal Nutrition. Butterworths, pp. 113-143

Mansbridge R. J., Blake S.J., 1997. Nutritional factors affecting the fatty acid composition in bovine milk. Brit. J. Nutr. 78, Suppl. 1, S37-\$47

Mazur A., Nassir F., Gueux E., Raissiguier Y., 1993. Plasma lipoproteins and apolipoproteins in copper deficient rats: studies on apolipoprotein synthesis and gene expresion. In: A. Anke, D. Meissner, C.F. Mills (Editors). Proceedings of the $8^{\text {th }}$ International Symposium on Trace Elements in Man and Animals - THEMA 8. Verlag Media Turistik, pp. 525-529

Pabst K., Walte H.G., 1991. Variation of cholesterol content in milk. Paper presented on $42^{\text {th }}$ EAAP Mecting, Berlin

Polish Standards (PN-68/A-86122), 1968. Milk. Investigation Methods (in Polish)

Potkański A., Nowak W., Szumaclser-Strabel M., Twardowska A., Mocek M., 1997. The effect of calcium soaps on milk yield and milk composition of forage fed cows (in Polish). Rocz. Nauk Zoot. 24 (3), 107-117

Rayssiguier Y.. Gueux E., Motta C., Mazur A.. 1993. Effect of copper deficiency in rats on lipoprotein and tissue peroxidation. In: A. Anke, D. Meissner, C.F. Mills (Editors). Proceedings of the $8^{\text {th }}$ International Symposium on Trace Elements in Man and Animals - THEMA 8. Verlag Media Turistik, pp. 530-534

Rogers P.A.M., 1996. Effective oral trace-element supplements for cattle and slieep. Teagasse, Grange Rescarch Centre, Dunsany (USA), Co. Meath, May 5, pp. 1-14

Roussel A.M., Richard M.J., Ravel A., Villet A., Alary J., 1993. Influence of zine defficiency on rat fatty acid distribution and peroxidation. In: A. Anke, D. Meissner, C. F. Mills (Editors). Proceedings of the $8^{\prime \prime}$ international Symposium on Trace Elements in Man and Animals - THEMA 8. Verlag Media Turistik, pp. $571-572$

Schauff D.J., Clark J.H., 1992. Effect of feeding diets containing calcium salts of long chain fatty acids to laclating dairy cows. J. Dairy Sci. 75. 2990-3002

Schauff D.J., Clark J.H., Drackley J.K., 1992. Effect of feeding lactating dairy cows diets containing extruded soybeans and calcium saits of long-chain fatty acids. J. Dairy Sci. 75, 3003-3019

West J.W., Hill G.M., 1990. Effect of protected fat product on productivity of lactating Holstein and Jersey cows. J. Dairy Sci. 73, 3200-3207 


\section{STRESZCZENIE}

\section{Wplyw dodatku cynku i soli wapniowych kwasów tluszczowych do dawek dla krów na wy- dajność i skład mleka $z$ uwzględnieniem cholesterolu}

W doswiadczeniu przeprowadzonym na 16 krowach rasy czb, w ukladzie kwadratu lacińskiego 2 $\mathrm{x} 2$, porównywano wplyw dodatku do diet kontrolnych $25 \mathrm{mg}$ cynku lub $60 \mathrm{~g}$ soli wapniowych kwasów tłuszczowych (CaFA) w postaci preparatu Erafet na wydajność i skład mleka z uwzględnieniem zawartości cholesterolu. Krowom grupy doświadczalnej podawano cynk w mieszance mincralnej $(80 \mathrm{~g} / \mathrm{dzień})$ wzbogaconej o $6 \mathrm{~g}$ cynku/kg. Krowy pobicrały średnio $19,2 \pm 0,28 \mathrm{~kg} / \mathrm{dzień}$ suchej masy dawki pokarmowej, w tym 12,1 $\pm 0,22 \mathrm{~kg}$ z kiszonek $\mathrm{z}$ traw i kukurydzy oraz $7,4 \pm 0,16 \mathrm{~kg} 7$ micszanki treściwej. Średnia wydajność mleka krów wynosiła $26,2 \pm 0,68 \mathrm{~kg} /$ dzień. Poziom cynku w dawee nie różnicowal istotnie wydajności mleka oraz ilości tłuszczu, białka i laktozy w mleku, chociaż zarysowała się tendencja spadku produkcji mleka o $0,9 \mathrm{~kg}$, a przy podawaniu CaFA wzrost o $0,9 \mathrm{~kg} / \mathrm{dzicń}$. Podawanie krowom CaFA obniżyło zawartość tłuszczu i białka w mleku $(\mathrm{P}<0,05)$, zwiększyło kwasowość j czas krzepnięcia $(\mathrm{P}<0,01)$ mlcka. Poziom cynku w dawce nie wpłynąt na zawartość frakcji azotowych w mleku, natomiast podanie z dawką soli CaFA spowodowało obniżenie stężeń $\mathrm{N}$-ogólnego, N-białkowego i N-kazeinowego $(\mathrm{P}<0,01)$ oraz nasyconych kwasów thuszczowych, natomiast podwyższyło stężenie nienasyconych kwasów tłuszzzowych $(\mathrm{P}<0,05)$. Zwiększenie pobrania cynku spowodowało wzrost jego stężcnia w osoczu krwi $(\mathrm{P}<0,01)$, natomiast po podaniu CaFA podwyższył się w osoczu poziom trójglicerydów, cholesterolu całkowitego, HDL $(P<0,05)$ i magnezu oraz aktywności fosfatazy alkalicznej. Stężenie cholesterolu całkowitego w mleku nie zmieniało siç istotnie po podaniu cynku bądż CaFA, a jego średni poziom wynosił $17,2 \pm 0,4 \mathrm{mg} / 100 \mathrm{ml}$ mleka. 